\title{
PARA GILDO MARÇAL BEZERRA BRANDÃO (1949-2010)
}

Ainda consternado pela infausta noticia, venho em nome do Conselho de Pesquisa e de todos os colegas do Cedec, registrar nosso imenso pesar pela perda de Gildo Marçal Brandão, amigo e companheiro, que integrava como vice-presidente a diretoria desta Instituição. Professor, intelectual, pesquisador consumado, Gildo exercia no Cedec liderança inspiradora, como coordenador de um vasto projeto coletivo: o projeto temático "Linhagens do pensamento politico-social brasileiro", desdobramento do programa de trabalho que deu origem à sua obra maior, o livro Linhagens do pensamento político

brasileiro, publicado em 2007. Não só isso. Atuando também no Conselho Editorial e no Comitê de Redação da Lua Nova, por muitos anos Gildo enriqueceu o Cedec com o vigor de sua têmpera, a lucidez de sua inteligência e a generosidade bem humorada de sua palavra. O Cedec é uma casa pequena, e Gildo ocupava um espaço muito grande nela. Não vai ser fácil preencher o vazio que sua partida deixa entre nós. Sebastião Velasco e Cruz 